\section{More words than action}

International trade in nuclear technology was a key issue at the 20th annual meeting of the International Atomic Energy Agency (IAEA) held in Rio de Janeiro last month. Bruce Handler reports from Brazil

ONE reason the IAEA meeting was held in Latin America was to encourage a better understanding of the problems facing developing countries in the field of nuclear energy. Nearly 1,400 delegates who attended wound up hearing almost as much about problems IAEA members have with each other as they have with nuclear cnergy, bccause a good portion of the debate consisted of political tirades. But everyone was in favour of the further development of nuclear energy. The sharp divisions were over which countries should assume the responsibility for developing it, and to what extent.

Many industrialised nations expressed fears over putting sophisticated nuclear technology into the hands of underdeveloped Third World countries, principally because of the widely shared belief that such countries could be encouraged or provoked into diverting this knowhow for military purposes. A corollary fear was that terrorists could stage a raid on an underdeveloped country that possessed nuclear reactors and steal the necessary components for making an atom bomb, even if the country in which this occurred was actually using atomic energy only for peaceful purposes.

The Third World rebuttal of this position was that underdeveloped countries could never progress if they are not allowed to acquire modern technology, in nuclear energy as well as in other fields. Developing countries described as discrimination the desire on the part of industrialised nations to limit the spread of such technology.

The IAEA's director-general, Sigvard Eklund, noted that many Third World countries have not signed the 1970 Nuclear Non-Proliferation Treaty because of this feeling. He appealed to them to reconsider the political reasons which originally led to their taking such a position but later recognised, realistically, that when it comes to national pride, nations sometimes refuse to listen to the most soberly reasoned arguments.

The country most strongly opposed to the sharing of nuclear technology was the United States. The head of the US delegation, Robert C. Seamans Jr., director of the US Energy Research and Development Administration, said in an address that the USA did not want to see sophisticated atomic knowhow spread throughout the developing world.

$\mathrm{He}$ said that countries which are taught how to enrich their own uranium for use in nuclear reactors could use this knowhow to separate plutonium from uranium. This, in turn, Seamans stated, "can increase the risk of diversion (of fissionable material) to nuclear weapons and also the risk of terrorist activities." The United States was willing to enrich uranium for other countries and make it widely available, but it was a risk to international security to show developing nations how to do their own enriching. Seamans added that as a compromise, the IAEA could set up regional uranium-enriching centres, which would at least be under multinational control.

Yugoslavia presented a proposal for creating a multinational pool of nuclear resources, to make it easier for developing countries to begin or expand nuclear energy programmes.

The IAEA meeting, however, was basically a forum, rather than a policymaking session, and the best any single delegate could hope for was that others would consider the proposals discussed and take them back to their home governments for study and possible implementation.

The Third World view on technology sharing was expressed most emphatically by Hervasio de Carvalho, the president of Brazil's Nuclear Energy Commission. He labelled the preoccupation over safeguards and the spread of nuclear technology to underdeveloped nations as "exaggerated", and repeated what Brazilian government officials have been trying to
One complete session of the IAEA meeting was devoted to the scientific discussion of advances that have been made in the use of nuclear technology in food and agriculture. Among the highlights:

- Dr Maurice I. Fried, of the United States, director of the Joint FAO/ IAEA Division of Atomic Energy in Food and Agriculture, gave a historical introduction to the use of nuclear techniques in the field of food and agriculture, and told delegates that isotope and radiation techniques "are neither esoteric nor so sophisticated that developing countries cannot apply them for the solution of practical problems." He noted that the bulk of the work of the joint FAO/ IAEA programme he heads is aimed at helping developing countries use atomic energy to improve their agricultural output.

- Dr Dick De Zeeuw, of the Netherlands, general director of agricultural rescarch of the Netherlands Ministry of Agriculture and Fisheries, offered the sombre forecast that by the year
2010 the world will have 1,800 million more people who consume less than the required daily amount of food than it does today, and that most of these new hunger victims will be in Southern and Southeast Asia. Many developing countries, he said, now lose from $20-40 \%$ of their crops after harvest; food-irradiation and related techniques could reduce this loss, but the main obstacle was the failure of policy-makers in developing countries to adopt the widespread use of atomic irradiation of food and to discard ineffective traditional methods.

- Dr K. Sundaram, of India, director of the biomedical group of the Bhabha Atomic Research Center in Bombay, made the point that effective food preservation techniques are difficult to transfer to underdeveloped ones, because of problems of money, materials, technology and energy of the poor nations' end. He said that developing nations around the world had failed to recognise irradiation's true importance, and criticised them for wrongly copying food preservation methods from developed countries, which, he noted, do not need to place so much importance on irradiation because of the already high standards of their food industries.

- Admar Cervellini, of Brazil, professor and head of the Physics and Meteorology Department of the University of Sao Paulo's Luiz de Queiroz Agricultural College, in Piracicaba, spoke about the work of Brazil's Centre for Nuclear Energy in Agriculture, of which he also is the head. The centre, which was set up with IAEA assistance, is now ten years old.

Dr Cervellini said that one of the centre's most practical achievements has been the development, through radiation mutation, of strains of beans with increased yield, with higher protein content, and with more resistance to Golden Mosaic disease. Seeds of the latter variety have been distributed to five other Latin American countries. 
explain to the rest of the world since the controversial nuclear deal with West Germany in 1975: that Brazil, which is poor in oil, has low-grade coal and is quickly using up its feasibly exploitable hydroelectric potential, has no other alternative but atomic energy for meeting its future electric-power needs. And for reasons of national security and common sense, Brazil cannot remain dependent on outside suppliers for nuclear fuel-as the United States would like.

Carvalho pointed out that even though Brazil has not signed the Nuclear Nonproliferation Treaty (for the usual reason: opposition to the division of the world into an elite, industrialised "atomic club" and everyone else), it has submitted the agreement with West Germany to IAEA safeguard supervision. This, he said, is proof that Brazil is not going to make any bombs, adding that the world should accept the word of other countries that make similar pledges to use atomic energy only for peaceful purposes. (The IAEA Board of Governors, which met in Rio before the general meeting, approved safeguard provisions in two other major transfer-of-tech- nology nuclear agreements: the one between Canada and Spain and that between France and South Africa.)

The Nigerian delegate's contention, that developing countries are in the IAEA "to be seen but not heard" and that they are "merely tolerated" by industrialised countries, did not seem to be reflected by the vote on a proposal sponsored by Iraq to admit the Palestine Liberation Organisation to the IAEA, as an observer. Of the 71 of the 110 member countries of the agency that were present for the vote, 46 voted in favour, 21 abstained and only four (Israel, the United States, South Africa and Costa Rica) voted no.

A move led by black African countries and supported by several socialist states to expel South Africa from the IAEA, on grounds that the Pretoria government does not represent the people, did not succeed. The best these countries could do was to get a motion passed to review South Africa's permanent seat on the Board of Governors, but with no action to be taken until the 1977 IAEA meeting. It is unlikely that even this watered-down proposal will bring results, because IAEA by-laws say the permanent regional scats on the board must go to the countries in each specific area of the world that are the most advanced in nuclear technology. In Africa, there is no doubt that this is South Africa.

The effect of nuclear power stations on the environment was another topic to come up at the meeting. Eklund expressed veiled dislike for citizens' movements which have sprung up in countries such as the United States to stop further construction of nuclear reactors. The IAEA chief asserted that nuclear power plants are "friends of the environment." He said there has never been a fatal accident from nuclear causes at any of the 180 nonmilitary nuclear installations now operating around the world. In contrast, Eklund noted, there have been serious accidents at hydroelectric plants, including the bursting of dams and the consequent widespread destruction of the environment.

Debate continued at the meeting on how best to dispose of waste material from nuclear reactors, by burying it in the ground, storing it in protected containers, dispersing it into the air or dumping it into the ocean. Perhaps predictably, no consensus was reached.

\section{New directions in lobbying}

A new lobbying organisation concerned with glohal scientific environmental and social issues was established in the United States last week. Colin Norman reports from Washington

Although Washington is thick with lobbyists, public interest groups, research organisations and assorted political hucksters selling commoditics ranging from the B-1 bomber to environmental awareness, the debut last wcek of a new 'citizens lobby' deserves -and is getting-more than passing attention.

Called 'New Directions', the organisation will be devoted to raising Washington's political consciousness (or at least, the consciousness of Washington's politicians) on such international issues as arms control, population growth, environmental pollution, and the depletion of resources. It will be an unabashed lobbying enterprise, focusing its attentions on the Congress. The reason it is already attracting considerable notice is that the list of its officers and governing board reads like a Who's Who of people concerned with such matters.

Full-time President of New Directions is Dr Russell W. Petcrson, former
Governor of Delaware, who recently resigned as Chairman of the Council on Environmental Quality to head the new group. And the outfit's executive council will be chaired by Dr Margaret Mead, the well-known anthropologist who has long been active in public interest causes associated with science.

Planning for New Directions began in the Summer of 1974, when Norman Cousins, editor of Saturday Review, and Theodore M. Hesburgh, president of the University of Notre Dame, convened a small group to discuss whether such an organisation is needed and if so, what form it should take. During the past two years, the planning group has expanded to more than 100 people, including such luminaries as Robert McNamara, head of the World Bank, Kingman Brewster, President of Yale University, James Grant, president of the Overseas Development Council, Lester Brown, head of the Worldwatch Institute, and Sargent Shriver, former dircctor of the Peace Corps.

The organisation will be similar in structure to Common Cause, a lobbying group which concentrates its attentions on domestic affairs. It will be a grass-roots organisation, financed by membership fees of $\$ 25$ per year, solicitations for which will soon be made through a direct mail campaign using membership lists of sympathetic organisations. New Directions hopes to attract at least 300,000 members, a number which would give it a very sizable war chest to put its message across.

Although the general nature of that message is evident from the concerns of the people associated with New Directions, priorities and details of the organisation's objectives are now being mapped out by groups of individuals working in the general areas of arms control, poverty and the widening economic gap between rich and poor nations, environment and natural reresources, human rights, and governmental decision-making.

There are already numerous organisations active in Washington in those areas, but New Directions hopes to provide an additional function-political lobbying to get the concerns raised by various public interest organisations through to the policy makers. Few existing organisations have been able to take on such a role hecause they would lose considerable tax advantages if they were to indulge in direct lobbying activities. Essentially, they are registered as educational or research outfits. Though a recent change in the tax laws has lifted some of those restrictions, few organisations are geared up to lobby actively.

A statement put out last week by the planning committee of New Directions 